\title{
A new synonym of Lophopyxis maingayi (Lophopyxidaceae)
}

\author{
I.M. Turner \\ Singapore Botanical Liaison Officer, \\ Royal Botanic Gardens Kew, \\ Richmond, Surrey TW9 3AE, U.K. \\ i.turner@kew.org \\ Singapore Botanic Gardens, National Parks Board, \\ 1 Cluny Road, 259569 Singapore
}

\begin{abstract}
Combretum perakense M.Gangop. \& Chakrab., described from specimens collected in Perak, Peninsular Malaysia, is here reduced to a synonym of Lophopyxis maingayi Hook.f. (Lophopyxidaceae). Lectotypes are designated for three other synonyms of Lophopyxis maingayi.
\end{abstract}

Keywords. Combretopsis, Combretum perakense, lectotypification, synonymy, Treubia

\section{Introduction}

In working on the Combretaceae for the Flora of Singapore, it was necessary to check the identity of taxa from the region in case any had direct relevance to material collected in Singapore. The most recently published new Combretaceae species for the area is Combretum perakense M.Gangop. \& Chakrab. (Gangopadhyay \& Chakrabarty, 1989). This species was described from several specimens collected by H.H. Kunstler (generally known as Dr King's Collector) from Perak in the 1880s. The authors of the name later questioned if their species really belonged in the Combretaceae and suggested Aspidopterys A.Juss. ex Endl. in the Malpighiaceae without reaching a definite conclusion (Gangopadhyay \& Chakrabarty, 1997: 362). Fortunately, I was able to obtain scans of the type material in CAL. This consists of fruiting specimens only. The terminal paniculate infructescences and winged fruits are very reminiscent of Combretum Loefl., but the alternate leaves are unusual for the genus, and close inspection of the images showed the fruits to be truly pedicellate with calyx remnants at the base. In Combretum, the flowers and fruits are generally sessile, and the ovary is markedly inferior with the calyx generally being shed with the distal part of the flower before fruit maturation. The question then became, if Combretum perakense did not belong in Combretum, where did it belong. The alternate leaves ruled out nearly all the Malpighiaceae, and after a few false starts, Lophopyxis maingayi Hook.f. was found to be an excellent match for the Combretum perakense specimens. Lophopyxis maingayi is the sole species of the genus Lophopyxis and family Lophopyxidaceae. It is a large woody climber, rather infrequently collected but with a wide range from Peninsular 
Malaysia and Peninsular Thailand (Utteridge, 2019) to the Solomon Islands and Micronesia in the South Pacific (Sleumer, 1969). The leaves are alternate and often notably serrate, but in some specimens, including the type, the leaves are more or less entire. The fruits are very combretum-like (as alluded to by at least two of the other names given to the plant), but the ovary is definitely superior.

Lophopyxis maingayi Hook.f., Hooker's Icon. Pl. 18: t. 1714(1887).-TYPE: Malaysia, Malacca, A.C. Maingay 2962 [Kew distrib. no. 1429] (lectotype K [K000736370, K000736369 - i.e. a single specimen over two sheets], designated by Sleumer, Blumea 16: 322 (1969); isolectotypes L [L0015475, L0015476]).

Combretopsis pentaptera K.Schum., Fl. Kais. Wilh. Land 69 (1889). - Lophopyxis schumannii Boerl., Handl. Fl. Ned. Ind. 1(2): 674 (1890), nom. illegit. (superfl.). Lophopyxis pentaptera (K.Schum.) Engl., Sitzungsber. Königl. Preuss. Akad. Wiss. Berlin 18: 265 (1893). - TYPE: New Guinea, Kaiser Wilhelmsland, Constantinhafen, 1887, M. Hollrung 609 (lectotype K [K000736368], designated here; isolectotype L [L0015481]).

Lophopyxis pierrei Boerl., Handl. Fl. Ned. Ind. 1(2): 673 (1890). - TYPE: Ceram, 1859-1860, de Vriese \& Teijsmann s.n. (lectotype L [L0015477], designated here).

Homalium gilgianum Lauterb., Nachtr. Fl. Schutzgeb. Südsee 320 (1905). - TYPE: New Guinea, Torricelli-Gebirge, April 1902, Schlechter 14565 (lectotype L [L0015480], designated here).

Combretum perakense M.Gangop. \& Chakrab., J. Econ. Taxon. Bot. 13: 687 (1989), syn. nov. - TYPE: Peninsular Malaysia, Perak, Larut, October 1884, Dr King's Collector [H.H. Kunstler] 6741 (holotype CAL [CAL0000010255]; isotypes CAL [2 sheets] [CAL0000010256, CAL0000010257]). (Fig. 1)

Boerlage (1890: 554) included a description of the genus Treubia, with a single species Treubia combretocarpa. However, before publication Boerlage realised that the genus had already been described by Hooker as Lophopyxis. Therefore, in a list of corrections at the end of the same part Boerlage noted that Treubia should be included in Lophopyxis and renamed Treubia combretocarpa as Lophopyxis pierrei. As this correction was published simultaneously with the original description, Treubia and T. combretocarpa were not validly published as Boerlage did not accept the names - ICN Art. 36.1 (Turland et al., 2018). Lophopyxis pierrei was validated by a diagnosis comparing leaf margin and shape of the leaf base with L. maingayi. In order to maintain continuity, I follow the type designation for Treubia combretocarpa by Sleumer (1969), though as this name is not validly published, Sleumer's designation has no standing and a new designation for Lophopyxis pierrei is made here. 


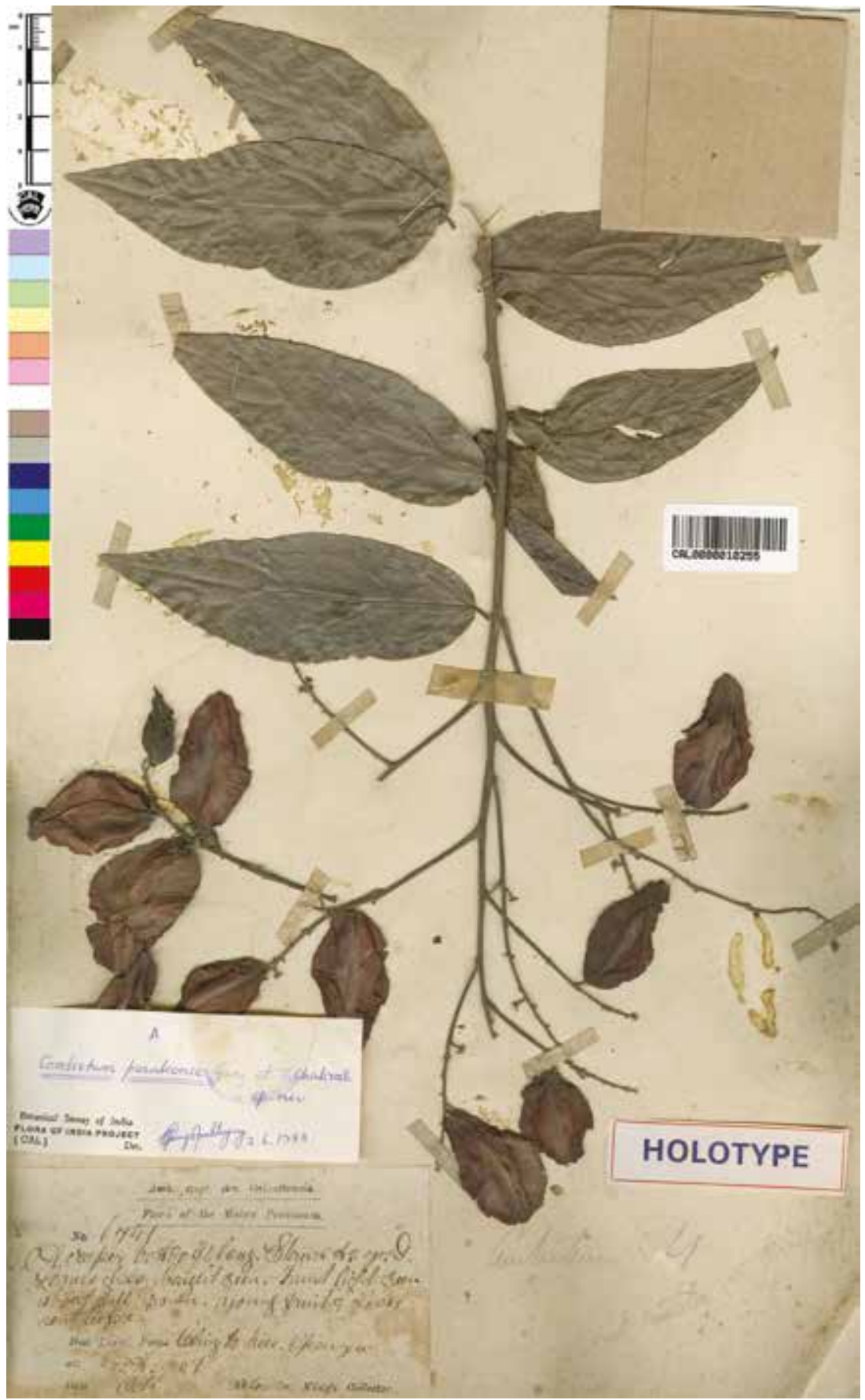

Fig. 1. Image of the holotype of Combretum perakense M.Gangop. \& Chakrab. Reproduced by kind permission of the Director, Botanical Survey of India. 
ACKNOWLEDGEMENTS. I am very grateful to V.P. Prasad and Anand Kumar (CAL) for facilitating access to the images of the type material of Combretum perakense.

\section{References}

Boerlage, J.G. (1890). Handleiding tot de kennis der flora van Nederlandsch Indië. Eerste deel, tweede stuk. Leiden: E.J. Brill.

Gangopadhyay, M. \& Chakrabarty, M. (1989). Notes on Asiatic Combretaceae. J. Econ. Taxon. Bot. 13: 685-689.

Gangopadhyay, M. \& Chakrabarty, M. (1997). The family Combretaceae of Indian Subcontinent. J. Econ. Taxon. Bot. 21: 281-364.

Sleumer, H. (1969 ['1968']). The genus Lophopyxis Hook.f. (Lophopyxidaceae). Blumea 16: 321-323.

Turland, N.J., Wiersema, J.H., Barrie, F.R., Greuter, W., Hawksworth, D.L., Herendeen, P.S., Knapp, S., Kusber, W.H., Li, D.Z., Marhold, K. et al. (eds) (2018). International Code of Nomenclature for algae, fungi, and plants (Shenzhen Code) adopted by the Nineteenth International Botanical Congress Shenzhen, China, July 2017. Regnum Vegetabile 159. Glashütten: Koeltz Botanical Books.

Utteridge, T.M.A. (2019). Lophopyxidaceae (Malpighiales): a new family record for Thailand. Thai For. Bull., Bot. 47: 11-15. 